УДК 351.746.1(477)

DOI https://doi.org/10.32782/2409-4544/2019-2/5

В. Окіпнюк

\title{
Державний і партійний контроль за органами державної безпеки УРСР у період панування тоталітарного режиму (1929-1953 pp.)
}

У статті досліджено основні форми контролю з боку державних і партійних органів за діяльністю, організаційною структурою та кадровим складом органів державної безпеки УРСР в умовах панування тоталітарного режиму. Встановлено, що в цей період відбувалися процеси послаблення державного і посилення партійного контролю за органами державної безпеки. Конституції СРСР 1936 р і УРСР 1937 р визначили приналежність НКВС-НКДБ-МДБ УРСР до категорії союзно-республіканських органів Народного комісаріату (міністерств) і наявність подвійного підпорядкування як РНК УРСР, так і відповідному союзно-республіканському наркомату (міністерству). Однак підпорядкованість органам влади УРСР носила формальний характер. Партійний контроль носив системний і всеосяжний характер. Його основними формами були: ознайомлення 3 документами i матеріалами про напрямки роботи, заслуховування звітів про результати, обстеження і перевірка підрозділів органів державної безпеки, попереднє схвалення проектів наказів наркома (міністра) державної безпеки. Існували певні колізії між загальносоюзним i республіканським законодавством у питаннях визначення юридичного статусу НКВС УРСР. Вони були усунуті з прийняттям Конституцій СРСР 1936 р. і УРСР 1937 р. Формально їх норми визначили належність НКВС УРСР до категорії союзно-республіканських народних комісаріатів і наявність подвійного підпорядкування як РНК УРСР, так і відповідному союзно-республіканському наркомату.

Ключові слова: органи державної безпеки, державний контроль, партійний контроль, Державне політичне управління (ДПУ), Народний комісаріат внутрішніх справ (НКВС), Народний комісаріат державної безпеки (НКДБ), Міністерство державної безпеки (МДБ).

Постановка наукової проблеми та її вивчення. У період панування в Україні тоталітарного режиму впродовж 1929-1953 рр. органи державної безпеки мали надзвичайно широкі повноваження в різних сферах діяльності. Однак не зважаючи на це, вони, які і всі інші ланки карального механізму, перебували під постійним контролем партійно-радянського керівництва СРСР і УРСР. Втім зміст, обсяг, види та напрями такого контролю змінювалися в залежності від етапів трансформації тоталітарної системи. Вивченням цієї проблематики у різний час займалися В. Д. Голіченко [1], В. В. Сенюшкін [2], Д. А. Тихоненков [3]. Водночас спеціального історико-правового дослідження, яке б висвітлювало здійснення контролю з боку партійно-державних структур за органами державної безпеки в період панування тоталітарного режиму в Україні, не проводилося.

Формулювання мети та завдань статті. Метою даної статті є історико-правовий аналіз стану державного та партійного контролю за органами ДПУ-НКВС-НКДБ-МДБ УРСР, висвітлення його основних форм і напрямів та оцінка ефективності. Поза рамками статті залишилися питання прокурорського нагляду за органами державної безпеки, як однієї з форм державного контролю, оскільки вони були предметом окремого дослідження автора.

Виклад основного матеріалу й обгрунтування отриманих результатів досліджень. На початку 1930-х рр. відповідно до ст.ст. 41 і 43 Конституції УСРР голова ДПУ УСРР хоч і входив до

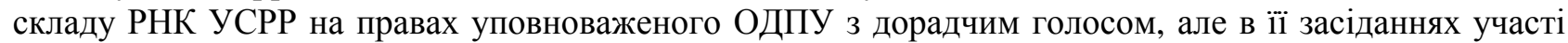
практично не брав. Відповідно припинилася і будь-яка звітність ДПУ перед ВУЦВК і РНК. Подібна тенденція в майбутньому тільки посилювалася.

Взаємовідносини місцевих органів державної безпеки з місцевими партійними і державними установами визначались статтями 73-74 Положення про структуру, оперативні й адміністративні функції та права місцевих органів ДПУ УСРР, затвердженого головою ДПУ УСРР у вересні 1930 р. Начальники міських і районних апаратів ДПУ мали інформувати міські і районні партійні та державні органи про політичний стан адміністративно-територіальних одиниць. Начальник сектору ДПУ під час виїзду до районів і міст міг вступати в контакт з міськими та районними партійними комітетами як офіційний представник ДПУ УСРР. Крім цього, у випадку загострення ситуації в певній місцевості начальник сектору ДПУ за необхідності мав право виступати на бюро або

(C) Окіпнюк B., 2019 
президіях місцевих партійних і державних органів з відповідними інформуванням [4, с. 517].

Юридичний статус НКВС УСРР відразу після його створення не був чітко визначений, адже положення про загальносоюзний НКВС хоча і було розроблене, однак офіційного затвердження не отримало [5, с. 51-52; 6, с. 37]. Саме воно, до речі, мало б детально регулювати діяльність республіканських наркоматів. До того ж, тільки 22 січня 1935 р., згідно з постановою ХІІ з’їзду Рад УСРР «Про зміни в Конституції (Основному законі) УСРР» [7] була скасована ст. 43, в якій закріплювався статус вже не існуючого ДПУ УСРР, і викладена у новій редакції ст. 44 Конституції УСРР 1929 p.

Але конституційні норми не внесли повної ясності у питання щодо статусу наркомату. Згідно 3 новою редакцією ст. 44 Конституції УСРР 1929 р. НКВС УСРР підпорядковувався ЦВК і РНК УСРР і одночасно у своїй діяльності здійснював директиви відповідних об'єднаних комісаріатів СРСР. У той же час, відповідно до згаданої вище постанови ЦВК СРСР від 10 липня 1934 р. НКВС СРСР вважався загальносоюзним, а не об'єднаним наркоматом.

Існуюча невідповідність була усунута 3 прийняттям нових союзної та республіканської конституцій. Статті 48 і 51 Конституції УРСР 1937 р. закріпили, що НКВС УСРР належить до союзно-республіканських народних комісаріатів та керує дорученими йому галузями державного управління, підпорядковуючись як РНК УРСР, так і відповідному союзно-республіканському наркомату [8, с. 13]. Звичайно, вказані норми мали формальний характер i фактичного підпорядкування НКВС УРСР органам державної влади республіки, зокрема РНК УРСР насправді так і не відбулось.

Після створення НКДБ УРСР 21 березня 1941 р. Верховна Рада УРСР внесла відповідні зміни та доповнення до статей 45 і 48 Конституції УРСР. НКДБ УРСР визначався в якості союзнореспубліканського наркомату, а нарком державної безпеки був введений до складу РНК УРСР. Але його діяльність в складі уряду носила формальний характер. Така ж ситуація мала місце й у повоєнний час, після перейменування НКДБ у МДБ.

Згортання державного контролю за органами державної безпеки з боку вищих та місцевих органів влади намагалися замінити внутрішньовідомчим контролем фінансово-господарської діяльності. В першій половині та середині 1930-х рр. було видано нормативні акти щодо бюджетної дисципліни та фінансової роботи в органах державної безпеки, а також проведено обстеження фінансової діяльності місцевих органів. Зокрема, це наказ ДПУ УСРР № 252 від 15 серпня 1932 p. i циркуляр НКВС УСРР № 14 «Про впорядкування фінансової роботи в місцевих органах НКВС УРСР» від 26 вересня 1936 р., які були спрямовані на зміцнення фінансової дисципліни, покращення діяльності секретарів-рахівників міськрайапаратів, удосконалення матеріального й фінансового обліку та звітності [9, арк. 125; 10, арк. 139; 11, арк. 97].

Ревізії фінансово-господарської діяльності місцевого апарату органів державної безпеки проводилися надалі. Так, наприклад, у 1948 р. таким перевіркам були піддані УМдБ Ворошиловградської, Закарпатської, Львівської, Чернігівської та Ізмаїльської областей, Львівська школа МДБ УРСР. У виданому 25 березня 1948 р. наказі МДБ УРСР № 026 «Про покращення фінансово-господарської діяльності в органах МДБ УРСР і посилення контролю за правильним $\mathrm{i}$ економним витрачанням грошових коштів і матеріальних цінностей» ФВ УМДБ наказувалося здійснювати ревізії міськрайорганів МДБ, виявляти факти порушень, незаконного витрачання коштів і розкрадань, проводити розслідування та притягати винних до відповідальності. Щоквартально матеріали ревізій мали доповідатися начальнику ФВ МДБ УРСР [12, арк. 68-70, 84-86; 13, арк. 36-40, 78-80, 102-103; 14, арк. 42-44].

Відомчий контроль за секретними видатками органів державної безпеки регулювався інструкцією НКВС СРСР № 177 від 28 серпня 1939 р. і передбачав щоквартальну перевірку секретної звітності за ст. 9 кошторису відомства спеціальними перевірними комісіями у складі керівництва основних оперативних підрозділів і ФВ НКВС-НКДБ-МДБ. Наприкінці 1947 - на початку 1948 рр. в МДБ УРСР на підставі інструкцій господарського управління та ФВ МДБ СРСР № 28ф-37ц від 11 вересня 1947 p. і ФВ МДБ СРСР № 28ф/17356 від 29 жовтня 1947 р. була проведена річна інвентаризація майнових і матеріальних цінностей, які перебували на обліку за лінією секретнооперативних витрат. У серпні 1948 р. були здійснені ревізії секретно-оперативних витрат в УМДБ Тернопільської, Чернігівської та Житомирської областей [15, арк. 185; 16, арк. 88-92; 17, арк. 73; 18, арк. 62, 154-156].

В умовах послаблення державного контролю за органами державної безпеки зростали роль і значення контрольних повноважень партійних структур. Партійний контроль стосувався найважливіших напрямів діяльності, організаційної структури та кадрового забезпечення органів 
державної безпеки.

Основними формами контролю з боку партійних структур за діяльності органів державної безпеки були ознайомлення 3 документами та матеріалами, які відображали результати цієї роботи, а також заслуховування звітів про іiі підсумки. Питання діяльності органів державної безпеки регулярно обговорювалися на засіданнях ПБ ЦК КП(б)У, обкомів і райкомів КП(б)У. Приймалися відповідні постанови партійних структур, у яких надавалася оцінка результатів цієї діяльності, передбачалося, в разі необхідності, застосування заходів впливу або притягнення до відповідальності. Органи державної безпеки надсилали до партійних інстанцій різноманітні звітні матеріали про свою діяльність - спецповідомлення, доповідні записки, довідки, листи тощо.

Значний обсяг звітної документації стосувався стану кадрової роботи в органах державної безпеки. Відповідні звіти, довідки, доповідні записки, статистичні дані регулярно направлялися до управління кадрів (з 1948 р. - адмінвідділу) ЦК КП(б)У, структур, які здійснювали контроль за станом укомплектованості та діяльністю органів НКДБ-МДБ. При цьому звітувалися як наркомат (міністерство) загалом, так і окремі УНКДБ-УМДБ зокрема.

Приміром, у звіті про роботу відділу кадрів НКДБ УРСР за період з липня 1943 р. по 1 січня 1945 р. керівництво НКДБ УРСР доповідало про формування кадрового складу органів державної безпеки після вигнання нацистів, стан апаратів НКДБ УРСР і УНКДБ областей, чисельність особового складу, його затвердження партійними інстанціями, роботу з висунення на вищі посади, проведення атестування, спеціальної перевірки співробітників, організаційно-штатні зміни та обліково-статистичну роботу [19, арк. 1-20]. До звіту додавалися відповідні довідки, відомості та списки [19, арк. 21-30].

У річному звіті відділу кадрів НКДБ УРСР за 1945 р. керівництво наркомату доповідало про підбір і комплектування кадрів, вивчення і розстановку особового складу, звільнення 3 органів працівників, які не відповідають вимогам роботи, підготовку, виховання та підвищення кваліфікації кадрів, облік кадрів і стан особових справ та спецперевірки, затвердження номенклатурного складу в партійних органах і НКДБ СРСР [20, арк. 1-17].

На виконання постанови ЦК КП(б)У від 29 серпня 1951 р. «Про недоліки в роботі з кадрами в міністерствах і відомствах Української РСР» та у зв’ язку з некомплектом кадрів МДБ УРСР просило ЦК КП(б)У прийняти спеціальну постанову про направлення 384 комуністів 3 посад секретарів $\mathrm{i}$ завідувачів відділів обкомів, міськкомів і райкомів КП(б)У для роботи в органах МДБ і міліції та ще 324 особи 3 партійних, радянських і комсомольських працівників областей на посади оперативного складу. Про недоліки в роботі з кадрами МДБ УРСР у цей же період подало до ЦК КП(б)У відповідну довідку. Проблеми кадрової роботи були обговорені на засіданні працівників кадрових підрозділів МДБ УРСР, яке відбулося в листопаді 1951 р. [21, арк. 271-272, 283-299, 372-469]

Контроль за станом кадрів на рівні обласних УНКДБ здійснювали місцеві партійні комітети. Вони виявляли некомплект номенклатурних посад, необхідність заміни керівних співробітників, які не відповідали займаним посадам або були малоефективними в роботі, та доповідали про це в ЦК КП(б)У [22, арк. 34-36; 23, арк. 12-22; 21, арк. 234-239].

Дієвою формою партійного контролю була перевірка, обстеження роботи окремих підрозділів органів державної безпеки. Наприклад, у вересні-жовтні 1948 р. комісією ЦК КП(б)У була проведена перевірка політико-морального стану особового складу відділу охорони МДБ УРСР. Вона встановила факти «нездорової обстановки» у відділі, парторганізація, яка налічувала 265 членів ВКП(б) і 38 кандидатів в члени ВКП(б), працювала, на думку комісії, незадовільно. На підставі цих матеріалів 5 жовтня 1948 р була прийнята постанова ПБ ЦК КП(б)У «Про політико-моральний стан особового складу відділу охорони МДБ УРСР» (протокол №179, п.8-3). За неналежне виконання керівництвом відділу своїх обов'язків начальник і заступник начальника були звільнені 3 посад. Міністру i секретарю партійного комітету МДБ УРСР наказувалося розробити заходи 3 «оздоровлення» колективу відділу. Ситуацію пропонувалося обговорити на партійному комітеті МДБ УРСР та провести «виховну роботу». До 1 січня 1949 р. міністр і секретар парткомітету МДБ були зобов’ язані прозвітувати до ЦК КП(б)У про виконання постанови [24, арк. 46-61].

Формою партійного контролю за діяльністю органів державної безпеки, яка вважалася винятковою прерогативою ЦК ВКП(б), було попереднє схвалення проектів наказів наркома (міністра) державної безпеки з особливо важливих питань агентурно-оперативної або слідчої діяльності. У такому порядку, наприклад, приймався згаданий раніше наказ МДБ СРСР № 00378 «ро покращення слідчої роботи в органах МДБ» від 24 липня 1947 р. та низка інших відомчих нормативних актів [4, c. 643-647; 25, арк. 100-106]. Так само приймалися рішення щодо важливих організаційно-штатних змін. 
Контроль за кадровим складом органів державної безпеки відбувався в кількох напрямах. Насамперед, партійні органи контролювали процес відбору та прийняття на службу співробітників. За постановою ОБ ЦК ВКП(б) від 11 червня 1930 р. для відбору кандидатів на роботу в органи ОДПУ при окружних партійних комітетах організовувалися спеціальні комісії в складі завідуючого кадрами окружного партійного комітету, начальника окрвідділу ДПУ та керівника відповідного підприємства. Вони направляли кандидатів на курси, що діяли при органах ДПУ [26, арк. 148].

Партійні структури повністю контролювали відбір кандидатів до відомчих закладів освіти органів державної безпеки. ПБ ЦК ВКП(б) і ПБ ЦК КП(б)У визначали кількісний склад кандидатів на навчання для кожної області, так звану розверстку, а на місцях створювалися комісії під головуванням секретарів обкомів, які здійснювали безпосередній відбір осіб.

Партійний контроль за органами державної безпеки забезпечувався ще й за рахунок прямих призначень партійних функціонерів на керівні посади в структури ДПУ-НКВС-НКДБ-МДБ. Процедура таких призначень, які ми умовно назвали «партійно-комсомольським призовом», активно застосовувалася з другої половини 1930-х рр.

Не останню роль у перетворенні органів державної безпеки у цілком контрольовану ВКП(б) структуру відіграла практика введення керівників ДПУ-НКВС-НКДБ-МДБ до складу вищих партійних інстанцій. У різний час до членами (кандидатами в члени) ЦК КП(б)У і ЦК ВКП(б), ПБ і ОБ ЦК КП(б)У були $\quad$ В. А. Балицький, К. М. Карлсон, $\quad$ I. М. Леплевський, $\quad$ С. Ф. Реденс, О. І. Успенський та інші.

Партійні інстанції встановили повний контроль за призначеннями на керівні посади як в системі центрального апарату, так i в місцевих органах НКВС-НКДБ-МДБ. На початку досліджуваного періоду було сформовано єдиний механізм призначення посадових осіб незалежно від їх місця в організаційно-штатній ієрархії. Кандидатури на посади від начальника районного відділення і вище мали бути погоджені по черзі Секретаріатом і ОБ та остаточно затверджені ПБ ЦК КП(б)У [27, с. 186-187].

Згодом було введено поняття «номенклатурні посади». Призначення та звільнення 3 них могли відбуватися тільки після рішення відповідного партійного органу, ЦК ВКП(б), ЦК КП(б)У, обкому КП(б)У, та виданого на підставі цього наказу союзного і республіканського наркомату (міністерства) або обласного управління державної безпеки.

Наприклад, на початок 1945 р. в органах НКДБ УРСР було 987 номенклатурних посад. Це 13 категорій керівних посад в місцевих органах і центральному апараті НКДБ УРСР [19, арк. 10, 23]. У 1945 р. кількість номенклатурних посад була збільшена до 1251 (779 посад - номенклатура ЦК ВКП(б) і НКДБ СРСР і 472 посади - номенклатура ЦК КП(б)У). Номенклатуру ЦК КП(б)У становили начальники райвідділень НКДБ УРСР, а вищі за них посади вважалися номенклатурою ЦК ВКП(б) і НКДБ СРСР. Подання матеріалів на затвердження мали здійснювати відділи кадрів органів НКДБ [28, арк. 7 зв. - 8 зв.].

Співробітники органів державної безпеки, які призначалися на номенклатурні посади i подавалися на затвердження в партійні інстанції, попередньо проходили спецперевірку. Наприклад, у листопаді 1945 р. в УНКДБ Кам'янець-Подільської області на 52 номенклатурні посади ЦК КП(б)У та НКДБ УРСР було затверджено в ЦК КП(б)У 40 осіб. Стосовно 12 осіб документи не подавалися через наявність на них компрматеріалів або у зв'язку з незавершеністю спец перевірки [22, арк. 97 101]. Компрматеріали могли бути підставою звільнення співробітників з номенклатурних посад за поданням обкому КП(б)У та рішенням ЦК КП(б)У [22, арк. 69-71].

На працівників НКДБ, які входили до номенклатури посад ЦК ВКП(б) і ЦК КП(б)У та відповідно НКДБ УРСР і НКДБ СРСР, обкоми партії мали надавати партійні характеристики. Часто місцеві партійні структури відмовлялися це робити. Тому в червні 1945 р. НКДБ УРСР просив ЦК КП(б)У дати вказівку обкомам КП(б)У про видачу таких документів відділам кадрів обласних УНКДБ [22, арк. 16, 38].

У післявоєнний час номенклатура посад МДБ УРСР була визначена циркуляром МДБ УРСР № 001 від 25 квітня 1947 р. [29, арк. 1-3]. Станом на 1 червня 1947 р. по всім органам МДБ УРСР до номенклатури ЦК ВКП(б), ЦК КП(б)У, МДБ СРСР і МДБ УРСР за списком входило 4889 посад, 3 яких 2510 були посадами керівного складу місцевих органів МДБ УРСР і 2379 - рядового складу центрального апарату МДБ УРСР [29, арк. 7-10].

Була розмежована компетенція вищих партійних інстанцій у питаннях призначення кандидатів на номенклатурні посади. Станом на березень 1947 р. міністра державної безпеки УРСР i його заступників, начальників 25 обласних УМДБ спочатку затверджувало ПБ ЦК КП(б)У, а остаточно - ПБ ЦК ВКП(б). Начальника Харківської міжкрайової школи МДБ - ОБ ЦК КП(б)У і ОБ 
ЦК ВКП(б). Призначення на всі інші номенклатурні посади затверджувалися рішеннями ПБ, ОБ або Секретаріату ЦК КП(б)У [29, арк. 4-6].

Система призначень на керівні посади в органах державної безпеки, яка сформувалася у післявоєнний час, забезпечила повний контроль з боку вищих партійних інстанцій СРСР, насамперед, ПБ ЦК ВКП(б), за призначеннями керівництва МДБ УРСР і УМДБ областей УРСР, а вищого партійного керівництва УРСР - за призначеннями керівників середньої ланки МДБ УРСР, УМДБ областей і підпорядкованих їм місцевих органів. Обкоми і райкоми КП(б)У контролювали призначення рядового оперативного та неоперативного складу обласних УМДБ, міських, районних i окружних відділів і відділень. Така система сприяла певній незалежності начальників обласних УМДБ від місцевого партійного керівництва, оскільки секретарі обкомів КП(б)У не мали впливу на процес призначення останніх. Водночас, начальники обласних УМДБ призначення своїх підлеглих мали узгоджувати 3 місцевими партійними структурами. Це був своєрідний тоталітарний аналог моделі «стримок і противаг», за рахунок якої досягався певний баланс інтересів різних партійних груп в керівництві ВКП(б) щодо здійснення кадрової політики в органах державної безпеки. Водночас, вказана модель дозволяла забезпечувати централізацію та обмежувала місцеві впливи при вирішенні кадрових питань.

Ще однією формою партійного контролю за органами державної безпеки був контроль за політичною благонадійністю співробітників та їх належне ідеологічне виховання. Для цього в структурі спецслужби створили партійні та комсомольські осередки. Вже наприкінці 1920-х рр. їх діяльність була спрямована на забезпечення відданості особового складу органів державної безпеки політиці, яка проводилася керівництвом ВКП(б), боротьбу 3 прибічниками опозиції в лавах спецслужби та усунення з посад небажаних з ідеологічних міркувань співробітників.

У 1930-ті pр. мережа партійних і комсомольських структур в органах державної безпеки була розширена, формувалися осередки окремих підрозділів, наприклад, ОВ КОВО [30, арк. 211-212], 3-х відділів (відділень) органів НКВС [26, арк. 157]. Вводилися посади звільнених секретарів парткомів УНКВС і НКВС УРСР [31, арк. 78-78 зв.].

В умовах зростання ролі та значення партійних осередків в органах державної безпеки, деякі 3 них намагалися перебирати на себе керівні функції. На засіданні ПБ ЦК КП(б)У від 11 липня 1939 р. (протокол №13, п.194-оп) з цього приводу була затверджена спеціальна постанова «Про рішення бюро первинних парторганізацій Житомирського та Ворошиловградського УНКВС». Зверталася увагу на те, що окремі бюро первинних парторганізацій обласних УНКВС, неправильно зрозумівши постанову ЦК ВКП(б) і РНК СРСР від 17 листопада 1938 р., втручаються в оперативну діяльність УНКВС, підміняють керівництво УНКВС, порушують принципи єдиноначальності та конспірації. ПБ ЦК КП(б)У наголошувало, що основне завдання первинних парторганізацій обласних УНКВС підвищувати ідейно-політичний рівень працівників УНКВС, виховувати в них «відчуття більшовицької пильності та безмежної відданості справі партії Леніна-Сталіна», зміцнювати дисципліну, допомагати керівництву УНКВС, вести боротьбу з недоліками в роботі [26, арк. 200205].

Однак намагання партійних осередків втручатися в службову діяльність органів державної безпеки продовжувалося й надалі. Так, Полтавський обком КП(б)У в серпні - вересні 1951 р. просив ЦК КП(б)У розділити первинну партійну організацію Полтавського УМДБ на дві окремі - для оперативних і адміністративно-господарських підрозділів. Мотивувалося таке прохання необхідністю більш «глибокого викриття» на партійних засіданнях недоліків і прорахунків в методах «оперативночекістської діяльності», тобто по суті прямого втручання партійних інстанцій в роботу органів МДБ [21, арк. 199-205].

На завершальному етапі Другої світової війни, в грудні 1944 р., була скликана перша партійна конференція НКДБ УРСР (у подальшому конференції скликалися майже щорічно). На ній зазначалося про відновлення старих і створення нових парторганізацій. Кількість комуністів в НКДБ УРСР зросла 3424 осіб (на 1 листопада 1943 р.) до 797 (на 29 грудня 1944 р.), діяло 14 первинних комсомольських організацій, до яких входило 256 співробітників [32, арк. 19-20, 33].

У підсумковій резолюції конференції серед основних задач партійних осередків були визначені: мобілізація всіх співробітників органів державної безпеки на виконання рішень ЦК ВКП(б), ЦК КП(б)У, обкомів і міськкомів КП(б)У, забезпечення службової дисципліни, прийняття в партію нових членів, політико-ідеологічна (політико-виховна) робота 3 «марксистсько-ленінського виховання комуністів», підвищення їх «ідейно-політичного рівня», контроль за вивченням співробітниками короткого курсу історії ВКП(б), книг Сталіна, іншої комуністичної літератури [32, арк. 180-186]. У цих питаннях партійні осередки органів державної безпеки мали звітувати перед 
відповідними інстанціями КП(б)У.

Проведена в грудні 1949 р. 5-та партійна конференція МДБ УРСР зобов'язала первинні партійні організації посилити ідейно-політичне виховання співробітників-комуністів і кандидатів в члени партії, вивчення ними «марксистсько-ленінської теорії», покращити керівництво комсомолом, зміцнити «чекістську» дисципліну та вчасно реагувати на iї порушення. На цю конференцію було обрано 296 делегатів, які представляли 1727 членів ВКП(б) і 141 кандидата в члени ВКП(б), в тому числі й комуністів первинних організацій органів міліції, які перейшли у відання МДБ [33, арк. 5868].

У жовтні 1950 р. до адміністративного відділу ЦК КП(б)У було направлено доповідь «Про стан виховної роботи в партійній організації МДБ УРСР». В цьому документі зазначалося, що основними засобами виконання рішень конференції була ідеологічна робота, спрямована на виховання співробітників органів державної безпеки «у дусі безмежної відданості партії, радянському уряду і особисто товаришу Сталіну». Тепер партійний комітет МДБ УРСР об'єднував 28 первинних партійних організацій, в яких перебувало 29 цехових організацій і 46 партійних груп із загальною кількістю в 2000 осіб. Після включення до МДБ УРСР органів міліції партійній організації МДБ УРСР підпорядкували 5 нових парторганізацій. В МДБ УРСР функціонувала комсомольська організація, в якій перебувало 406 осіб.

3 метою посилення політико-ідеологічного виховання особового складу при партійних комітетах органів державної безпеки УРСР були запроваджені партійні кабінети. В них зберігалася політична, загальноосвітня та художня література, наочна агітація, діяли інститути штатних i позаштатних пропагандистів і агітаторів з історії та теорії більшовицької партії [34, арк. 247-261, 270282, 289-302].

Партійний комітет МДБ УРСР займався «партійною освітою» і загальноосвітнім навчанням співробітників, організацією культурно-просвітницьких заходів, керував діяльністю комсомольської організації, здійснював поповнення партійного складу, розглядав порушення партійної та службової дисципліни тощо [34, арк. 212-236].

Місцеві партійні комітети контролювали «марксистсько-ленінське навчання» в парторганізаціях обласних управлінь і доповідали про його стан в ЦК КП(б)У. Наприклад, в листопаді 1950 р. в УМДБ Рівненської області з 275 членів і кандидатів в члени ВКП(б) та 45 комсомольців на курсах вечірнього університету марксизму-ленінізму при УМДБ навчалося 89 осіб, самостійно вивчали «історію і теорію більшовицької партії» 55 осіб, інші працівники управління навчалися у вечірній партійній школі, гуртках з вивчення історії ВКП(б) і політшколі при міськкомі КП(б)У [34, арк. 286-288].

У грудні 1950 р. відбулася 6 партійна конференція МДБ УРСР, на яку було обрано 318 делегатів з правом вирішального і 14 з правом дорадчого голосу, що представляли 1871 члена ВКП(б) і 159 кандидатів в члени ВКП(б). У резолюції партконференції наголошувалося на необхідності зміцнювати первинні партійні організації в органах державної безпеки та підвищувати рівень організаційно-партійної, партійно-політичної та політико-виховної роботи. Остання мала бути спрямована, насамперед, на посилення службової дисципліни та зростання «комуністичної свідомості чекістів». Для цього велика увага приділялася партійній пропаганді, роботі різноманітних політшкіл, гуртків, лекторіїв 3 «марксистсько-ленінської теорії» тощо [34, арк. 487-497, 508-517].

Партійний комітет МДБ УРСР також здійснював поточне інформування та звітував перед адмінвідділом ЦК КП(б)У. Звіти через відповідні обкоми до ЦК КП(б)У щорічно подавали й парторганізації обласних УМДБ. Крім цього, до вищих партійних інстанцій передавалися плани роботи партбюро парторганізацій МДБ, матеріали звітно-виборчих зібрань первинних партійних організацій МДБ тощо. Ці документи свідчили про встановлення тотального партійного контролю за особовим складом органів державної безпеки як у сфері службової діяльності, так і приватного життя співробітників [34, арк. 327-398, 427-476; 35, арк. 1-53; 36, арк. 1-70; 33, арк. 52-58, 97-114, 148-159, 212-295].

3 вересня 1951 р., після призначення колишнього 1-го секретаря Станіславського обкому КП(б)У М. В. Слоня на посаду заступника міністра державної безпеки УРСР по кадрам, партійний контроль за органами МДБ ще більш посилився. Зокрема, пропонувалося централізувати роботу всіх парторганізацій МДБ УРСР і покласти на них попереднє обговорення та надання характеристик щодо тих працівників, які підлягали підвищенню по посаді [21, арк. 499-500].

Висновки. Таким чином, державний контроль за органами державної безпеки, його форми, методи і характер визначалися юридичним статусом ДПУ-НКВС-НКДБ-МДБ та їх місцем в системі державного механізму. Існували певні колізії між загальносоюзним i республіканським 
законодавством у питаннях визначення юридичного статусу НКВС УРСР. Вони були усунуті 3 прийняттям Конституцій СРСР 1936 р. і УРСР 1937 р. Формально їх норми визначили належність НКВС УРСР до категорії союзно-республіканських народних комісаріатів і наявність подвійного підпорядкування, як РНК УРСР, так і відповідному союзно-республіканському наркомату. Однак, незважаючи на це, реальна невідповідність між фактичним і юридичним статусом НКВС, а в подальшому НКДБ і МДБ, так і не була викорінена. У досліджуваний період, на тлі концентрації контрольних функцій в партійних структурах, державний контроль був формалізований, а згодом i майже припинений. Його намагалися замінити внутрішнім самоконтролем фінансово-господарської діяльності.

Партійні структури здійснювали системний i всеохоплюючий контроль за діяльністю, організаційною структурою та кадровим складом органів державної безпеки. Основними формами партійного контролю були: ознайомлення 3 документами та матеріалами про напрями роботи, заслуховування звітів про ії результати, обстеження та перевірка підрозділів органів державної безпеки, попереднє схвалення проектів наказів наркома (міністра) державної безпеки з особливо важливих питань агентурно-оперативної, слідчої діяльності та змін і трансформацій організаційноштатної структури органів державної безпеки.

У сфері кадрового складу контроль здійснювався на всіх етапах кадрової роботи: починаючи 3 відбору кандидатів на службу, висунення й призначення на керівні посади та завершуючи здійсненням політико-виховної роботи серед співробітників. Основними формами при цьому були: участь партійних працівників у комісіях з відбору на службу; погодження призначень в партійних органах на так звані номенклатурні посади; звітування перед партійними органами про кадрову роботу та її основні напрями; організація та функціонування партійних і комсомольських осередків в органах державної безпеки, підпорядкованих відповідним партійним і комсомольським структурам; впровадження обов'язкового партійно-політичного виховання особового складу органів державної безпеки; введення керівництва органів державної безпеки різного рівня до складу відповідних партійних органів - ЦК ВКП(б), ЦК КП(б)У, обкомів, міськкомів і райкомів КП(б)У тощо.

Державний контроль, який перетворювався на формальність, практично не впливав на організацію та діяльність органів державної безпеки. Втім партійний контроль набував все більшого значення і ставав важелем за допомогою якого комуністична партія тримала ці органи в своїх руках $\mathrm{i}$ спрямовувала на виконання поставлених завдань.

\section{Джерела та література}

1. Голіченко В. Д. Партійне керівництво органами державної безпеки. На матеріалах України / Г. В. Доліченко. - Київ: Вид-во Київ. ун-ту, 1968. - 184 с.

2. Сенюшкин В. В. Руководство Коммунистической партии органами ЧК в период гражданской войны и иностранной интервенции (по материалам Юга Украины, январь 1918 - февраль 1922): автореф дис... канд. истор. наук / В. В. Сенюшкин. - Одесса, 1967. - 22 с.

3. Тихоненков Д. А. Проблеми контролю та нагляду за органами ВУНК-ДПУ УСРР у 1918 - на початку 1929 рр.: автореф. дис. ... канд. юрид. наук: 12.00.01 / Д. А. Тихоненков. - Харків, 1998. $18 \mathrm{c}$.

4. Лубянка: Органы ВЧК-ОГПУ-НКВД-НКГБ-МГБ-КГБ. 1917-1991. Справочник. Под ред. акад. А. Н. Яковлева. Авторы-сост.: А. И. Кокурин, Н. В. Петров. - М.: МФД, 2003. - 768 с.

5. Плотникова Н. С. Проблемы правового регулирования деятельности органов государственной безопасности НКВД СССР/ Н. С. Плотникова // Материалы исторических чтений на Лубянке. 19972000 гг. Российские спецслужбы. История и современность. - Москва, 2003. - С. 48-52.

6. Коровин В. В. История отечественных органов безопасности. - Москва, 1998. - 253 с.

7. С3 УССР. 1935. № 8-9. СТ. 41.

8. Конституция (Основной закон) Украинской Советской Социалистической Республіки. - Киев, 1938. -31 с.

9. Галузевий державний архів Служби безпеки України. - Ф. 9. - Спр. 287.

10. Галузевий державний архів Служби безпеки України. - Ф. 9. - Спр. 290.

11. Галузевий державний архів Служби безпеки України. - Ф. 9. - Спр. 666.

12. Галузевий державний архів Служби безпеки України. - Ф. 9. - Спр. 135.

13. Галузевий державний архів Служби безпеки України. - Ф. 9. - Спр. 138.

14. Галузевий державний архів Служби безпеки України. - Ф. 9. - Спр. 139.

15. Галузевий державний архів Служби безпеки України. - Ф. 9. - Спр. 121. 
16. Галузевий державний архів Служби безпеки України. - Ф. 9. - Спр. 122.

17. Галузевий державний архів Служби безпеки України. - Ф. 9. - Спр. 141.

18. Галузевий державний архів Служби безпеки України. - Ф. 9. - Спр. 142.

19. Центральний державний архів громадських об'єднань України. - Ф. 1. - Оп. 23. - Спр. 2431.

20. Центральний державний архів громадських об'єднань України. - Ф. 1. - Оп. 23. - Спр. 2422.

21. Центральний державний архів громадських об’єднань України. - Ф. 1. - Оп. 24. - Спр. 876.

22. Центральний державний архів громадських об’єднань України. - Ф. 1. - Оп. 23. - Спр. 2427.

23. Центральний державний архів громадських об’єднань України. - Ф. 1. - Оп. 23. - Спр. 2432.

24. Центральний державний архів громадських об’єднань України. - Ф. 1. - Оп. 16. - Спр. 72.

25. Галузевий державний архів Служби безпеки України. - Ф. 9. - Спр. 17 (СРСР).

26. Центральний державний архів громадських об’єднань України. - Ф. 1. - Оп. 16. - Спр. 34.

27. Окіпнюк В. Т. Органи державної безпеки УРСР (1922-1941рр.): історико-правове дослідження: монографія / 2-ге вид., доопр. та доповн. / В. Т. Окіпнюк. - Херсон: ФОП Грінь Д. С., 2017. - 390 с.

28. Центральний державний архів громадських об’єднань України. Ф. 1. Оп. 23. Спр. 2426.

29. Галузевий державний архів Служби безпеки України. - Ф. 9. - Спр. 127.

30. Центральний державний архів громадських об’єднань України. - Ф. 1. - Оп. 16. - Спр. 30.

31. Центральний державний архів громадських об’єднань України. - Ф. 1. - Оп. 16. - Спр. 32.

32. Центральний державний архів громадських об’єднань України. - Ф. 1. - Оп. 23. - Спр. 1367.

33. Центральний державний архів громадських об’єднань України. - Ф. 1. - Оп. 24. - Спр. 385.

34. Центральний державний архів громадських об’єднань України. - Ф. 1. - Оп. 24. - Спр. 386.

35. Центральний державний архів громадських об’єднань України. - Ф. 1. - Оп. 24. - Спр. 388.

36. Центральний державний архів громадських об’єднань України. - Ф. 1. - Оп. 24. - Спр. 389.

Окипнюк В. Государственный и партийный контроль за органами государственной безопасности УССР в период господства тоталитарного режима (1929-1953 гг.). В статье исследованы основные формы контроля со стороны государственных и партийных органов за деятельностью, организационной структурой и кадровым составом органов государственной безопасности УССР в условиях господства тоталитарного режима. Установлено, что в этот период происходили процессы ослабления государственного и усиления партийного контроля за органами государственной безопасности. Конституции СССР 1936 г. и УССР 1937 г. определили принадлежность НКВД-НКГБ-МГБ УССР к категории союзно-республиканских органов Народного комиссариата (министерств) и наличие двойного подчинения как СНК УССР, так и соответствующему союзно-республиканскому наркомату (министерству). Однако подчиненность органам власти УССР носила формальный характер. Партийный контроль носил системный и всеобъемлющий характер. Его основными формами были: ознакомление с документами и материалами о направлениях работы, заслушивание отчетов о результатах, обследования и проверка подразделений органов государственной безопасности, предварительное одобрение проектов приказов наркома (министра) государственной безопасности. Существовали определенные коллизии между общесоюзным и республиканским законодательством в вопросах определения юридического статуса НКВД УССР. Они были устранены с принятием Конституции СССР 1936 г. и Конституции УССР 1937 г. Формально их нормы определили принадлежность НКВД УССР к категории союзнореспубликанских народных комиссариатов и наличие двойного подчинения как СНК УССР, так и соответствующему союзно-республиканском наркомата.

Ключевые слова: органы государственной безопасности, государственный контроль, партийный контроль, Государственное политическое управление (ГПУ), Народный комиссариат внутренних дел (НКВД), Народный комиссариат государственной безопасности (НКГБ), Министерство государственной безопасности (МГБ).

Okipniuk V. State and Party Control over the State Security Bodies in the Ukrainian SSR under the Totalitarian Regime (1929-1953). The article analyzes the principal forms of state and party authorities control over the activity, organizational structure, and personnel of the state security institutions under the totalitarian regime. The study has revealed that during that period, the processes of weakening of the state and strengthening of party control over the state security bodies were very intensive and systemic. The Constitutions of the USSR of 1936 and the Ukrainian SSR of 1937 determined the affiliation of the NKVD - NKDB - MGB of the USSR to the the Union-Republican People's Commissariats (ministries) and validated their double subordination, both to RNA of the USSR and the corresponding Union-Republican ministry. However, subordination to the authorities of the Ukrainian SSR was rather formal than real. Party 
control was systemic and all-embracing. Its main forms were: familiarization with party documents and materials on the directions of work, discussing the reports on the results and achievements, inspection and authorization of the units in the state security institutions, preliminary approval of the decrees issued by the People's Commissar (Minister) of state security. There were some conflicts between the all-Union and republican legislation in determining the legal status of the NKVD of the USSR. They were abolished with the adoption of the Constitutions of the USSR in 1936 and the USSR in 1937. Formally, their norms defined the NKVD of the USSR to the category of union-republican people's commissariats and the existence of double subordination, both the SNK of the USSR and the corresponding union-republican People's Commissariat.

Key words: State Security Authorities, State Control, Party Control, State Political Administration (DPU), People's Commissariat of Internal Affairs (NKVD), People's Commissariat of State Security (NKDB), Ministry of State Security (MGB).

\section{Володимир Старосольський - відомий вчений-правник, адвокат, політик}

У статті досліджені основні напрямки діяльності видатного українського правника початку XX ст. В. Старосольського, розглянуто його біографію. В. Старосольський - відомий український громадсько-політичний діяч, адвокат. Він був типовим представником українсько-польського прикордоння, походив із змішаної сім'ї. Він стає активним захисником у національному правозахисному русі в Західній Україні. Як адвокат бере активну участь в політичних процесах польських властей проти украінцв-членів ОУН, УВО, громадських і політичних діячів різної ідеологічної орієнтації В. Старосольський намагався впливати на процес конструктивного розв'язання болісної української проблеми у Польщі. В. Старосольський завжди вважав, що найкращою формою вирішення конфліктів у українсько-польських взаєминах $\epsilon$ діалог. В. Старосольський протягом свого непересічного життя обіймав посади заступника міністра закордонних справ Української Народної Республіки (1919-1920рр.), доктора права і професора Українського державного університету в Кам'янці-Подільському (1919-1920рр.), Українського вільного університету в Празі (1921-1928 рр.) і Української Господарської академії в Подебратах (1922-1928 рр.). Як громадський діяч і адвокат він був дійсним членом Наукового товариства ім. Т. Шевченка у Львові (1923р.), головою Української соціал-демократичної партії (1937-1939рр.), Членом-засновником Товариства українських юристів у Львові (1909р.), членом правління Спілки українських адвокатів у Львові (1929-1939 рр.), Львівської палати адвокатів (1928-1939 рр.), Вищій раді адвокатів Польщі у Варшаві (1937-1939 рр.), членом-засновником Українського юридичного товариства у Чехословаччині (1923 р). У науковій сфері В. Старосольський реалізував себе як член редакцій юридичних журналів, автор ряду юридичних і соціологічних робіт, монографій, посібників.

Ключові слова: Володимир Старосольський, науковець, адвокат, громадський діяч.

Постановка проблеми. Володимир Старосольський - відомий український громадськополітичний діяч, правник, адвокат. Він був типовим представником українсько-польського прикордоння, походив зі змішаної родини. I у певний період часу постало питання про те, яку національність обрати. I В. Старосольський обирає українську. Він стає активним захисником українців в українському правозахисному русі на Західній Україні. Як адвокат бере активну участь у політичних процесах польської влади проти українців - членів ОУН, УВО, громадських і політичних діячів різної ідейної орієнтації. У статті розкриваються питання життя В. Старосольського, формування його політичної та громадянської позиції, становлення його як адвоката та науковця.

Стан дослідження. Сучасні дослідження 3 історії української політико-правової думки містять лише перші спроби осмислення теоретичної спадщини Володимира Старосольського. Окремі питання політико-правового і соціального життя, участі Володимира Старосольського у судових політичних процесах над українцями в Польщі, його громадської і політичної праці досліджувались

(C) Тищчик Б., Новосядло I., 2019 